\title{
Digestibility in Lactating Cows of Diets Containing Whole Pima Treated with Sodium Hydroxide Versus Akala or Pima Cottonseed
}

\author{
R. Solomon, ${ }^{1}$ G. Adin, ${ }^{1}$ S. J. Mabjeesh, ${ }^{2}$ M. Nikbachat, ${ }^{3}$ E. Yosef, ${ }^{3}$ D. Ben-Ghedalia, ${ }^{3}$ and J. Miron ${ }^{3}$ \\ ${ }^{1}$ Ministry of Agriculture, Israeli Extension Service, Department of Cattle Husbandry Bet-Dagan, Israel \\ ${ }^{2}$ Department of Animal Science, The Faculty of Agricultural Food and Environmental Quality Sciences, \\ PO Box 12, Rehovot, Israel \\ ${ }^{3}$ Institute of Animal Science, Department of Dairy Science, Agricultural Research Organization \\ The Volcani Center, PO Box 6, Bet-Dagan, Israel
}

\begin{abstract}
This study examines the effect of $\mathrm{NaOH}$ treatment on the nutritive value of Pima cottonseed for lactating cows. Treatment of Pima cottonseed with $\mathrm{NaOH}$ increased the extent of dry matter (DM) and neutral detergent fiber in vitro digestibility. Three groups of cows were fed 3 similar total mixed rations (TMR) differing only in the type of cottonseed fed, either whole linted Akala, whole unlinted Pima, or whole Pima treated with $4 \% \mathrm{NaOH}$ (T-Pima). Dry matter and organic matter $(\mathrm{OM})$ intakes of Akala and Pima TMR were similar and tended to be lower compared with cows fed T-Pima. This was reflected in similar intake of crude protein and lipids by cows fed the 3 TMR. Digestibility of DM, $\mathrm{OM}$, and crude protein were similar in cows fed Pima and T-Pima diets, and slightly higher in cows fed the Akala TMR. Lipid digestibility was highest in cows fed Akala TMR, whereas cellulose and NDF digestibility were lowest in Pima TMR. In the 3 TMR, there was a large gap between the high values of "digestibility of intact seeds" and actual in vivo digestion of DM and OM. Similar yields of milk and milk protein were obtained in cows fed the Akala and Pima TMR, whereas higher yields of milk, milk protein, milk fat, and $4 \%$ fatcorrected milk were found in the T-Pima cows. Similar efficiency of DM intake for fat-corrected milk production was achieved by cows fed the 3 TMR.
\end{abstract}

(Key words: $\mathrm{NaOH}$-treated Pima cottonseed, linted Akala cottonseed, digestibility in lactating cows, milk production)

Abbreviation key: T-Pima = Pima cottonseed treated with $4 \% \mathrm{NaOH}$.

\section{INTRODUCTION}

Cottonseed has long been used as a common feedstuff included at a level of 10 to $20 \%$ in lactating cow rations

Received November 18, 2004.

Accepted February 14, 2005.

Corresponding author: J. Miron; e-mail: jmiron@volcani.agri. gov.il. because of its high content of energy, mainly in the form of oil, moderately high level of $\mathrm{CP}$, and high content of effective NDF (Clark and Armentano, 1993; Arieli, 1998). Two types of cottonseed are supplied to farmers by the cotton gin industry: the "Akala" white type cottonseed (Gossypium hirsutum) that contains a high concentration of lint, and the "Pima" black variety (Gossypium barbedense), which is unlinted. The lint is composed of short cotton strands that remain attached to the cottonseed after ginning, and represents about 10 to $12 \%$ of total weight in Akala cottonseed (Moreira et al., 2004).

Numerous studies have demonstrated beneficial effects of feeding whole linted cottonseed on the yield of milk and milk fat of lactating dairy cows (Clark and Armentano, 1993; Arieli, 1998; Harvatine et al., 2002). However, much less research data is available describing the feeding value of Pima cottonseed. This information is important because production of Pima cotton has increased in the last decade because of the extra long staple length of the cotton, which is desired for the manufacturing properties of cotton fiber. Unlinted cottonseed contains more protein and fat and less NDF than high-lint cottonseed (Sullivan et al., 1993a; Moreira et al., 2004). A potential problem associated with feeding of whole Pima cottonseed is the appearance of undigested whole seed in feces (Sullivan et al., 1993a,b; Zinn, 1995). It was claimed that unlinted cottonseed tends to sink in the rumen, is less masticated, and therefore less digested in the rumen than conventional linted cottonseed (Coppock et al., 1985; Sullivan et al., 1993b; Zinn, 1995). Some studies demonstrated higher milk production in cows fed whole Akala cottonseed compared with feeding whole Pima (Sullivan et al., 1993b). Feeding cracked or roasted Pima cottonseed to lactating cows has resulted in comparable milk and FCM production as whole linted cottonseed (Sullivan et al., 1993a,b), and better FCM production compared with untreated Pima cottonseed (Sullivan et al., 1993b; Mabjeesh et al., 2000). Other studies suggested that under certain conditions, unlinted cottonseed might 
yield similar or higher milk compared with linted cottonseed (Kutches et al., 1987; Moreira et al., 2004). This discrepancy between studies needs further comparison to assess the nutritive value for dairy cows of whole unlinted Pima cottonseed compared with whole linted Akala seeds.

Chemical treatment of whole cereal grains with liquid sodium hydroxide disrupts the seed coat by partial solubilization of hemicellulose and lignin and causes swelling of the outer cellulose- and cutin-rich coat, so that rumen bacteria gradually gain access to the grain endosperm (Orskov et al., 1980; Miron et al., 1997). Arieli et al. (1996) evaluated in situ the effect of $\mathrm{NaOH}$ treatment of nonlinted Pima cottonseed, and found that this treatment increased ruminal and lower tract DM disappearance. Based on the study of Arieli et al. (1996), and on the observation that more intact cottonseeds are excreted in feces of cows fed Pima compared with Akala, $\mathrm{NaOH}$ treatment has been extensively used by feed manufacturers in Israel, on the assumption that it will improve the digestibility of Pima cottonseed by lactating dairy cows. However, there is a lack of knowledge in the literature about the digestibility in lactating dairy cows of $\mathrm{NaOH}$-treated Pima cottonseed, and a lack of any in vivo comparison in lactating cows among TMR containing either $\mathrm{NaOH}$-treated Pima, highlinted Akala, or untreated Pima cottonseed, to support this assumption.

The objectives of this study were 1) to examine the effect of $\mathrm{NaOH}$ treatment on chemical composition and extent and rate of in vitro digestibility of Pima cottonseed; and 2) to evaluate the digestibility and performance in lactating dairy cows of TMR containing up to 18\% NaOH-treated whole Pima cottonseed (T-Pima) compared with whole untreated Pima and whole linted Akala.

\section{MATERIALS AND METHODS}

\section{Digestion and Milk Production Study}

Eighteen multiparous Holstein cows $(2.4 \pm 0.10$ lactations) were fed during a pre-experimental period of 3 wk a TMR containing 9\% Akala cottonseed (Gossypium hirsutum) plus 9\% Pima cottonseed (Gossypium barbedense); other ingredients of the pre-experimental TMR were as described for the experimental TMR shown in Table 1. At the end of the basal period and onset of the experiment, cows were divided into 3 groups of 6 cows each (3 blocks, later assigned as treatments), similar in average (mean $\pm \mathrm{SE})$ stage of lactation $(96 \pm 6.1$ DIM), daily milk yield (30.4 $\pm 0.85 \mathrm{~kg})$, and BW (570 \pm $8.2 \mathrm{~kg}$ ). Cows were housed during the trial in conventional stanchions $(140 \times 180 \mathrm{~cm})$ in a well-ventilated barn, under continuous lighting during night hours, and were milked twice a day at 0600 and $1800 \mathrm{~h}$. Experimental conditions were under the supervision of the Israeli Committee of Animal Welfare. During an experimental period of $35 \mathrm{~d}$, each cow was fed ad libitum one of the 3 types of TMR (Table 1). All 3 TMR contained $18 \%$ cottonseed, and differed only in the type of cottonseed fed; either whole linted Akala, whole low-lint Pima, or Pima cottonseed treated with $4 \% \mathrm{NaOH}$. Total mixed rations also contained $33 \%$ wheat silage, $29.5 \%$ starchy grains, protein sources, $\mathrm{Cr}_{2} \mathrm{O}_{3}$ marker, vitamins, and minerals, as shown in Table 1. The $\mathrm{NaOH}$ treatment was done by mixing whole Pima grains with commercial $\mathrm{NaOH}$ solution at a level of $40 \mathrm{~g}$ of NaOH/ $\mathrm{kg}$ of DM Pima seeds. The treated cottonseeds (T-Pima) contained $21 \%$ moisture and were kept under plastic cover for $48 \mathrm{~h}$ before feeding. Fresh TMR was offered at $1000 \mathrm{~h}$ after the collection of orts from the previous day, which were weighed and kept in a freezer $\left(-20^{\circ} \mathrm{C}\right)$ until analysis. Water was available continuously. The experimental period lasted $35 \mathrm{~d}$, including a 7-d adaptation to rations followed by a 28-d treatment period. Milk production was monitored daily. Milk samples were collected during 2 milkings on Wednesday of each week during the 5-wk experimental period. Each set of milk samples for each cow was stored at $4^{\circ} \mathrm{C}$ in the presence of bromide compounds as preservative, until analyzed for content of fat, protein, lactose, and urea by infrared analysis (AOAC, 2000), using a Milkoscan 4000 (Foss Electric, Hillerød, Denmark). Daily DMI was determined by subtracting average DM of orts from DM of TMR offered to each cow.

The last $6 \mathrm{~d}$ of the experimental period were assigned for daily sampling of cottonseeds, TMR, feed refusals, and feces. Chromium oxide, as an unabsorbed marker for digestibility determination, was mixed with TMR components. The $\mathrm{Cr}_{2} \mathrm{O}_{3}$ concentration in the TMR was designed to reach the level of $10 \mathrm{~g}$ of $\mathrm{Cr}_{2} \mathrm{O}_{3} /$ cow per d (Miron et al., 1997). Estimation of daily fecal excretion was based on marker concentrations in feces and in TMR. Fecal grab samples were taken twice daily for 6 $\mathrm{d}$, at 12 -h intervals, each day $2 \mathrm{~h}$ later than the preceding day. Fecal samples were composited (on a DM basis) for each cow during the collection period and lyophilized. Freeze-dried samples of the 3 TMR and cottonseeds were composited on a weekly basis. Part of the cottonseeds, TMR, feed refusals, and wet feces samples of each cow were used for enumeration of intact seeds, after washing and filtering the materials through a 1$\mathrm{mm}$ sieve, to calculate the proportion of intact (undigested) cottonseeds excreted in feces, and the "digestibility" of whole cottonseeds. Another part of the dry feeds, feed refusals, and feces samples of each cow were ground through a 1-mm screen and used for preparation of NDF and further analyses. 
Table 1. Composition of the Akala, Pima, and NaOH-treated Pima (T-Pima) TMR fed to lactating dairy cows.

\begin{tabular}{lcccc}
\hline & \multicolumn{3}{c}{ Dietary TMR } \\
\cline { 2 - 4 } Ingredient, kg/ton of DM & Akala & Pima & T-Pima & SEM \\
\hline Linted Akala cottonseed & 180 & $\ldots$ & $\ldots$ \\
Unlinted Pima cottonseed & $\ldots$ & 180 & $\ldots$. \\
NaOH-treated Pima & $\ldots$ & $\ldots$. & 180 \\
Rolled barley grain & 176 & 176 & 176 \\
Ground corn grain & 119 & 119 & 119 \\
Wheat silage & 330 & 330 & 330 \\
Soybean meal & 69.0 & 69.0 & 69.0 & \\
Sunflower meal & 34.0 & 34.0 & 34.0 & \\
Corn gluten feed & 33.0 & 33.0 & 33.0 & \\
Wheat bran & 22.0 & 22.0 & 22.0 & \\
Marker + vitamin-mineral mixture ${ }^{1}$ & 37.0 & 37.0 & 37.0 & \\
Composition, \% of DM & & & & \\
DM, \% & 59.8 & 57.8 & 57.9 & 0.65 \\
OM & 91.6 & 91.3 & 90.9 & 0.56 \\
CP & 17.8 & 17.9 & 17.5 & 0.23 \\
Ether extract & 5.90 & 6.10 & 5.53 & 0.44 \\
NDF & $38.2^{\mathrm{a}}$ & $35.4^{\mathrm{b}}$ & $35.9^{\mathrm{b}}$ & 0.39 \\
Cellulose & $17.5^{\mathrm{a}}$ & $14.5^{\mathrm{b}}$ & $14.8^{\mathrm{b}}$ & 0.41 \\
Hemicellulose & 14.5 & 13.9 & 14.9 & 0.38 \\
Lignin & 6.17 & 6.97 & 6.23 & 0.27 \\
\hline
\end{tabular}

a,b,c Means in the same row followed by different superscripts differ at $P<0.05$.

${ }^{1}$ Marker + vitamin-mineral mixture contained (kg per ton of DM TMR): $2.0, \mathrm{Na}_{2} \mathrm{SO}_{4} ; 5.0, \mathrm{MgCO}_{3} ; 12.5$, dicalcium phosphate; $10.5, \mathrm{CaCO}_{3} ; 5.0 \mathrm{NaCl} ; 0.5, \mathrm{Cr}_{2} \mathrm{O}_{3}$ marker; 1.5 trace minerals plus vitamins mix containing 24,000,000 U vitamin $\mathrm{A} ; 4,800,000 \mathrm{U}$ vitamin $\mathrm{D}_{3} ; 90,000 \mathrm{U}$ vitamin $\mathrm{E} ; 75.0 \mathrm{~g} \mathrm{Mn} ; 105 \mathrm{~g} \mathrm{Zn} ; 45$ g Fe; 48 g Cu; 5.1 g I; 0.48 g Co; 0.72 g Se.

\section{Chemical Analyses and In Vitro Digestibility}

Five weekly samples of the 3 types of cottonseeds and TMR, and individual feed refusals and feces were assayed in triplicate for DM, OM, and ether extract (AOAC, 2000); CP was determined according to the Kjeldahl method (AOAC, 2000). The NDF, ADF, and acid detergent lignin contents (excluding residual ash), were determined in triplicate according to the method of Van Soest et al. (1991), with heat-stable amylase and sodium sulfite, and by employing Ankom apparatus (Ankom Technology, Fairport, NY) for extraction and filtering. Chromium oxide was determined by atomicabsorption spectrometry as described previously (Miron et al., 1997). The density and volume of the 3 types of cottonseeds were measured in the 5 weekly composites (replicates) by weighing the total amount of dry seeds loosely filling a 10-L container.

Extent of DM and NDF in vitro digestibility of the 3 types of cottonseed ground through a 1-mm sieve was analyzed in each weekly composite sample in triplicate using $48 \mathrm{~h}$ of incubation with rumen fluid, followed by an additional 48-h incubation with $\mathrm{HCl}$ and pepsin, according to the 2-stage fermentation technique of Tilley and Terry (1963). Residual NDF in the in vitro tubes was determined according to Van Soest et al. (1991). Ruminal fluid was obtained before morning feeding via esophageal tube from 2 cows fed the Akala TMR, 2 cows fed the Pima TMR, and 2 cows fed the T- Pima TMR. All rumen fluid samples were combined to create one pooled sample, and used for the in vitro measurements. Rate of in vitro DM digestibility of the 3 types of cottonseed was measured similarly except that the first stage of incubation was conducted in triplicate during 0,6 , $12,24,48$, or $72 \mathrm{~h}$ of fermentation with rumen fluid followed by additional 48-h fermentation with $\mathrm{HCl}$ and pepsin. Rate of in vitro DM digestion was determined as the slopes of the first-order kinetic equation describing the regression between $\log _{\mathrm{e}}$ (residual fraction $\%-$ undigested fraction \%) against time of incubation (h), as shown by Mertens and Loften (1980).

\section{Calculations and Statistical Analyses}

The daily yield per cow of $4 \%$ FCM was calculated according to the NRC (2001) equation:

$4 \% \mathrm{FCM}(\mathrm{kg})=0.4 \times$ milk $(\mathrm{kg})+15.0 \times$ milk fat $(\mathrm{kg})$

Differences between the 3 types of cottonseeds in chemical composition and in vitro digestibility were analyzed statistically using the JMP 5 software of SAS (SAS Institute, 1996), using Tukey's test to differentiate between means.

Digestibility and intake results of individual cows were analyzed statistically by the standard ANOVA 
Table 2. Chemical and physical characteristics and in vitro digestibility of the 3 types of cottonseed.

\begin{tabular}{lccrr}
\hline & \multicolumn{3}{c}{ Type of cottonseed ${ }^{1}$} \\
\cline { 2 - 4 } Parameter & Akala & Pima & T-Pima & SEM \\
\hline DM, \% & $92.1^{\mathrm{a}}$ & $91.5^{\mathrm{a}}$ & $79.3^{\mathrm{b}}$ & 1.21 \\
OM, \% of DM & $95.8^{\mathrm{a}}$ & $94.0^{\mathrm{a}}$ & $88.0^{\mathrm{b}}$ & 1.12 \\
CP, \% of OM & $24.3^{\mathrm{b}}$ & $26.4^{\mathrm{a}}$ & $26.4^{\mathrm{a}}$ & 0.22 \\
Ether extract, \% of OM & $22.9^{\mathrm{b}}$ & $27.7^{\mathrm{a}}$ & $26.4^{\mathrm{a}}$ & 0.52 \\
NDF om, \% of OM & $50.6^{\mathrm{a}}$ & $44.9^{\mathrm{b}}$ & $46.1^{\mathrm{b}}$ & 1.25 \\
Cellulose, \% of OM & $35.5^{\mathrm{a}}$ & $18.4^{\mathrm{b}}$ & $19.7^{\mathrm{b}}$ & 0.82 \\
Hemicellulose, \% of OM & $6.47^{\mathrm{b}}$ & $12.7^{\mathrm{a}}$ & $12.8^{\mathrm{a}}$ & 0.69 \\
Lignin, \% of OM & $8.66^{\mathrm{b}}$ & $13.8^{\mathrm{a}}$ & $13.6^{\mathrm{a}}$ & 0.36 \\
In vitro DM digestibility, \% & $39.3^{\mathrm{b}}$ & $43.6^{\mathrm{b}}$ & $50.6^{\mathrm{a}}$ & 1.58 \\
Rate of DM digestibility, \%/h & 4.00 & 3.64 & 3.70 & 0.23 \\
In vitro NDF digestibility, \% & $24.1^{\mathrm{ab}}$ & $20.1^{\mathrm{b}}$ & $28.8^{\mathrm{a}}$ & 1.44 \\
Seeds density, kg of DM/L & $0.38^{\mathrm{c}}$ & $0.58^{\mathrm{b}}$ & $0.62^{\mathrm{a}}$ & 0.04 \\
Seeds per kg of DM & $8750^{\mathrm{b}}$ & $9268^{\mathrm{a}}$ & $8673^{\mathrm{b}}$ & 140 \\
\hline a,b,c Means in the same row followed by different superscripts differ at $P<0.05$. & \\
1Akala = High linted Akala cottonseed; Pima $=$ unlinted Pima cottonseed; T-Pima = unlinted Pima treated \\
with 4\% NaOH.
\end{tabular}

design. Milking performance data were reduced to means by cow in the $28 \mathrm{~d}$ of the experimental period after $7 \mathrm{~d}$ of adaptation to the diets. These data were analyzed in completely randomized ANOVA design using the GLM procedure of SAS (SAS Institute, 1996). Because cows were allocated to 3 groups (blocks) similar in their performance and DIM at the onset of the experiment, and because blocking factor was not significant with respect to milk yield and DMI $(P=0.55$ and 0.32 , respectively), there was no need for covariate adjustments.

\section{RESULTS AND DISCUSSION}

\section{Cottonseeds Characterization and In Vitro Digestibility}

The first objective of this study was to evaluate the effect of $\mathrm{NaOH}$ treatment of unlinted Pima cottonseed on the chemical composition and in vitro digestibility compared with untreated Pima and linted Akala cottonseeds. Composition data of the 3 types of cottonseeds are shown in Table 2. Data show that Pima cottonseed is characterized by higher content of CP, lipids, hemicellulose, and lignin, and lower content of cellulose and total NDF compared with the lint-rich Akala cottonseeds. The lint of Akala, which is composed of short cotton strands (pure cellulose) that remain attached to the cottonseed after ginning and represent about 10 to $12 \%$ of total weight, is the main cause of these compositional differences between cottonseeds, as demonstrated in previous studies (Coppock et al., 1985; Sullivan et al., 1993a; Zinn, 1995). Treatment of Pima cottonseed with $\mathrm{NaOH}$ did not change fat and $\mathrm{CP}$ content compared with untreated Pima; treated and untreated Pima seeds had higher levels of fat and CP than Akala
(Table 2). Cell wall polysaccharides, cellulose, and hemicellulose, as well as lignin components of Pima were hardly solubilized by $\mathrm{NaOH}$ treatment.

The in vitro DM digestibility values of Akala and Pima cottonseeds were similar (39.3 and 43.6\%, respectively). This low digestibility originated from the very low NDF digestibility of Akala and Pima (24.1 and $20.1 \%$, respectively), because NDF contributes a major part (41 to $50 \%$ ) of cottonseed mass. Treatment with $\mathrm{NaOH}$ increased DM and NDF in vitro digestibility compared with untreated Pima (Table 2), but did not affect the rate of $\mathrm{DM}$ in vitro digestibility. This in vitro picture agrees with results from a previous in situ study comparing $\mathrm{NaOH}$-treated and untreated Pima cottonseeds (Arieli et al., 1996). It was suggested that $\mathrm{NaOH}$ treatment disrupts the seed coat by partial cleavage of linkages within the hemicellulose-lignin matrix, and causes swelling of the outer hulls, which are rich in lignin and cutin, so that rumen bacteria gradually gain access to the grain endosperm and NDF polysaccharides. It should be mentioned that extent of DM and NDF in vitro digestibility was examined in ground substrates $(1 \mathrm{~mm})$ under well-buffered conditions, $(\mathrm{pH}$ in the range of 6.6 to 7.0). Therefore, the in vitro data indicate the maximal potential of seed digestion. However, these digestibility values might be reduced in vivo because of accessibility obstacles of rumen bacteria to digest intact seeds protected by the envelope, and incomplete rumination due to the high level of intake and high rate of passage from the rumen of the $\mathrm{NaOH}$ treated seeds.

Some physical characteristics of the various cottonseeds are also given in Table 2. The highest density ( $\mathrm{kg}$ of DM/L) was obtained in the unlinted wet T-Pima cottonseeds that stuck together, the lowest in the high 
Table 3. Intake and digestibility of dietary components consumed by lactating dairy cows.

\begin{tabular}{lccccc}
\hline & \multicolumn{3}{c}{ Dietary treatment ${ }^{1}$} & & \\
\cline { 2 - 4 } Parameter & Akala & Pima & T-Pima & SEM & $P<$ \\
\hline Intake, kg/cow per d & & & & & \\
DM & 20.9 & 20.5 & 22.5 & 0.66 & 0.11 \\
OM & 19.1 & 18.7 & 20.4 & 0.60 & 0.14 \\
CP & 3.70 & 3.68 & 3.91 & 0.08 & 0.33 \\
Ether extract & 1.23 & 1.25 & 1.23 & 0.02 & 0.91 \\
NDF & $7.94^{\mathrm{ab}}$ & $7.23^{\mathrm{b}}$ & $8.08^{\mathrm{a}}$ & 0.20 & 0.02 \\
Cellulose & $3.61^{\mathrm{a}}$ & $2.92^{\mathrm{b}}$ & $3.33^{\mathrm{a}}$ & 0.11 & 0.05 \\
Hemicellulose & $3.05^{\mathrm{ab}}$ & $2.86^{\mathrm{b}}$ & $3.35^{\mathrm{a}}$ & 0.11 & 0.04 \\
Whole seeds $\times 10^{3} /$ cow per d & $182.9^{\mathrm{b}}$ & $190.0^{\mathrm{ab}}$ & $195.1^{\mathrm{a}}$ & 2.86 & 0.05 \\
Digestibility, \% & & & & & \\
DM & $64.2^{\mathrm{a}}$ & $61.9^{\mathrm{b}}$ & $60.4^{\mathrm{b}}$ & 0.60 & 0.03 \\
OM & $66.1^{\mathrm{a}}$ & $64.0^{\mathrm{b}}$ & $62.4^{\mathrm{b}}$ & 0.60 & 0.03 \\
CP & $71.1^{\mathrm{a}}$ & $67.3^{\mathrm{b}}$ & $66.9^{\mathrm{b}}$ & 1.23 & 0.05 \\
Ether extract & $92.2^{\mathrm{a}}$ & $78.8^{\mathrm{b}}$ & $78.8^{\mathrm{b}}$ & 1.94 & 0.01 \\
NDF & $40.7^{\mathrm{a}}$ & $36.2^{\mathrm{b}}$ & $39.3^{\mathrm{ab}}$ & 1.06 & 0.03 \\
Cellulose & $42.2^{\mathrm{a}}$ & $32.8^{\mathrm{b}}$ & $44.3^{\mathrm{a}}$ & 1.59 & 0.03 \\
Hemicellulose & $48.1^{\mathrm{a}}$ & 45.7 & 48.8 & 1.40 & 0.59 \\
Whole cottonseeds & $98.4^{\mathrm{a}}$ & $89.3^{\mathrm{b}}$ & $87.3^{\mathrm{b}}$ & 1.61 & 0.03 \\
\hline
\end{tabular}

${ }^{\mathrm{a}, \mathrm{b}, \mathrm{c}}$ Means in the same row followed by different superscripts differ at $P<0.05$.

${ }^{1} \mathrm{Akala}=\mathrm{TMR}$ containing $18 \%$ high linted whole Akala cottonseed; Pima $=$ TMR containing $18 \%$ unlinted whole Pima cottonseed; T-Pima $=$ TMR containing $18 \%$ whole Pima treated with $4 \% \mathrm{NaOH}$.

lint Akala seeds, with the unlinted Pima cottonseeds in an intermediate position. Thus, the presence of lint increased the volume of Akala cottonseed, a parameter that has economic implications for bulk storage and cost. More seeds were found per gram of dry Pima compared with Akala and T-Pima. This finding is important for comparing digestibility in lactating cows of the whole cottonseeds.

\section{TMR Composition, Intake, and Digestibility}

The 3 TMR of this study differed only in the type of cottonseed fed (at a level of $18 \%$ of TMR DM), being either whole linted Akala, whole unlinted Pima, or whole Pima treated with $4 \% \mathrm{NaOH}$ (Table 1). Chemical composition data of dietary OM, CP, ether extract, NDF, and NDF-polysaccharides are shown in Table 1. Dry matter, OM, and ether extract concentrations were similar in the 3 TMR (Table 1). However, NDF and cellulose content were higher in Akala TMR than in the 2 Pima TMR, and this reflects the higher content of these components originating from the lint of Akala cottonseed (Table 1). In the 3 TMR, about $50 \%$ of the $\mathrm{NDF}$ originated from wheat silage, 20 to $25 \%$ from the cottonseeds, and the remainder from concentrated feeds.

Intake and digestibility data of the 3 TMR fed to lactating cows are shown in Table 3. Dry matter intake of Akala and untreated Pima TMR were similar and tended to be slightly lower $(P=0.11)$ compared with the TMR of T-Pima. This was reflected in similar intake of $\mathrm{OM}, \mathrm{CP}$, and ether extract by cows fed the 3 dietary treatments. However, intakes of NDF, cellulose, and hemicellulose were lower in Pima TMR compared with the T-Pima diet. The total number of whole cottonseeds ingested in Akala TMR was lower than that of the TPima TMR.

Digestibility of DM, OM, and CP was similar in cows fed the Pima and T-Pima TMR diets, and lower than that of the cows fed Akala cottonseeds. Digestibility of hemicellulose was similar in the 3 TMR; however, digestibility of cellulose was higher in Akala and TPima diets than in Pima TMR. In accordance with this data, DM and OM digestibility values tended to be slightly higher in cows fed 15\% whole Akala as substitute for whole Pima cottonseeds (Sullivan et al., 1993a,b). In the present study, the digestibility of lipids in cows fed Akala TMR was higher than that of cows fed the 2 Pima TMR (92 vs. 79\%, respectively, $P<0.01$, Table 3). This lipid digestion gap between treatments is in accord with the previous study of Sullivan et al. (1993a) and deserves further explanation. Coppock et al. (1985) postulated that the absence of lint changed the stratification of cottonseed within the rumen, resulting in lower rumen digestibility of acid-delinted seeds in the rumen than of linted cottonseed. Support for this assumption was later given by Zinn (1995), who showed better digestion of whole Akala seeds in the rumen of steers than of whole Pima seeds, and postruminal compensation of Pima digestion, resulting in similar total tract digestibility of the 2 types of cottonseeds. It is therefore suggested that the higher digestion of Akala seeds in the rumen results in better disruption of seed envelopes, cleavage of Akala triglycerides, and 
Table 4. Milk yield and composition of lactating dairy cows fed 3 TMR differing in type of cottonseed.

\begin{tabular}{|c|c|c|c|c|c|}
\hline \multirow[b]{2}{*}{ Parameter } & \multicolumn{3}{|c|}{ Dietary treatment } & \multirow[b]{2}{*}{ SEM } & \multirow[b]{2}{*}{$P<$} \\
\hline & Akala $^{1}$ & Pima $^{2}$ & T-Pima ${ }^{3}$ & & \\
\hline Milk yield, $\mathrm{kg} / \mathrm{d}$ & $32.2^{\mathrm{b}}$ & $33.1^{\mathrm{ab}}$ & $34.5^{\mathrm{a}}$ & 0.42 & 0.04 \\
\hline Milk fat, $\%$ & $3.89^{\mathrm{a}}$ & $3.53^{\mathrm{b}}$ & $4.01^{\mathrm{a}}$ & 0.07 & 0.02 \\
\hline Milk protein, \% & $3.44^{\mathrm{a}}$ & $3.27^{\mathrm{b}}$ & $3.50^{\mathrm{a}}$ & 0.05 & 0.03 \\
\hline Milk lactose, \% & 4.95 & 4.83 & 4.93 & 0.05 & 0.51 \\
\hline Milk urea, $\%$ & $0.050^{\mathrm{a}}$ & $0.044^{\mathrm{b}}$ & $0.041^{\mathrm{b}}$ & 0.001 & 0.02 \\
\hline Milk fat, kg/d & $1.25^{\mathrm{b}}$ & $1.17^{\mathrm{c}}$ & $1.38^{\mathrm{a}}$ & 0.02 & 0.01 \\
\hline Milk protein, $\mathrm{kg} / \mathrm{d}$ & $1.11^{\mathrm{b}}$ & $1.08^{\mathrm{b}}$ & $1.21^{\mathrm{a}}$ & 0.02 & 0.01 \\
\hline $4 \%$ FCM yield, $\mathrm{kg} / \mathrm{d}$ & $31.7^{\mathrm{b}}$ & $30.7^{\mathrm{b}}$ & $34.5^{\mathrm{a}}$ & 0.52 & 0.01 \\
\hline Efficiency, DMI/FCM & 0.66 & 0.67 & 0.65 & 0.01 & 0.56 \\
\hline
\end{tabular}

${ }^{\mathrm{a}, \mathrm{b}, \mathrm{c}}$ Means in the same row followed by different superscripts differ at $P<0.05$.

${ }^{1} \mathrm{Akala}=\mathrm{TMR}$ containing $18 \%$ high linted whole Akala cottonseed $;$ Pima $=$ TMR containing $18 \%$ unlinted whole Pima cottonseed; T-Pima $=$ TMR containing $18 \%$ whole Pima treated with $4 \% \mathrm{NaOH}$.

fatty acids hydrogenation by ruminal microorganisms, compared with Pima cottonseeds. Therefore, more protected triglycerides containing nonhydrogenated fatty acids are flowing to the lower gut of animals fed the 2 Pima diets. According to Zinn (1995), the lipids of Pima escaping rumen fermentation are less absorbed in the lower tract compared with Akala lipids. This might explain the difference in lipids digestion between Akala and the 2 Pima TMR (Table 3).

The higher digestibility of cellulose in TMR of Akala and T-Pima (42.2 and 44.3\%, respectively) compared with Pima TMR (32.8\%) can be explained in the case of Akala by the higher proportion of cellulose originated from Akala's lint, which is readily digestible in the rumen (Coppock et al., 1985; Sullivan et al., 1993a). For T-Pima, the swelling effect of treatment on the cellulose fraction of Pima seeds may increase the digestibility of $\mathrm{NDF}$ and cellulose by rumen bacteria as shown in vitro (Table 2). Moreover, it was previously suggested that $\mathrm{NaOH}$ released from treated cereal grain in the rumen might act as a buffer and elevate ruminal $\mathrm{pH}$ to an adequate level $(>6.4)$ for ruminal cellulolytic bacteria, and might increase the rate of passage of the liquid phase containing soluble carbohydrate from the rumen (Orskov et al., 1980). Thus, $\mathrm{NaOH}$ treatment of grains was suggested as effective in reducing the inhibitory "carbohydrate effect" on ruminal cellulolytic bacteria and create favorable conditions for cell wall digestion in the rumen (Orskov et al., 1980; Miron et al., 1997). This might partially explain the advantage of the TPima TMR over Pima diet with respect to cellulose and NDF digestion.

Cottonseed enumeration in the feeds, orts, and wet feces samples (after washing and filtering through a $1.0-\mathrm{mm}$ sieve) enabled calculation of the proportion of intact (undigested) cottonseeds excreted in feces, and the "digestibility" of whole cottonseeds. Data in Table 3 show the higher "digestibility" of whole cottonseeds in Akala TMR compared with the 2 Pima TMR (98 vs. $89 \%$, respectively). This finding is in agreement with previous comparisons of whole seed excretion in feces between whole Akala and whole Pima diets (Sullivan et al., 1993a,b; Zinn, 1995) and supports our explanation above regarding the differences in lipid and cellulose digestion. However, in all 3 TMR, most of the cottonseeds $(>87 \%)$ were disrupted and ground during rumination and passage through the entire tract, showing a high gap between "digestibility of whole seeds" values and actual in vivo digestion of cottonseed DM and OM (Table 3).

\section{Milking Performance}

The number of cows per dietary treatment $(n=6)$ used in this study was adequate for conducting in vivo digestion studies (Sullivan et al., 1993a; Zinn, 1995; Miron et al., 1997) but should be considered a preliminary observation regarding intake and milking performance. Performance data in Table 4 show similar yields of milk, FCM, and milk protein in cows fed the Akala and Pima TMR. However, cows fed the T-Pima TMR had higher yields of fat and FCM compared with the other 2 treatments. Similar milk and FCM production by cows fed either whole unlinted or linted cottonseeds were demonstrated in previous studies (Sullivan et al., 1993a; Moreira et al., 2004). The advantage in milk fat and milk protein production of the cows fed T-Pima compared with the untreated Pima TMR (Table 4) originated mostly from the higher DMI of cows and also from the better NDF and cellulose digestibility discussed above (Table 3). However, the similar efficiency of DMI for FCM production of the 3 dietary treatments (0.65 to 0.67 , Table 4) suggests that the main cause of the higher FCM production of the T-Pima TMR in this study is its better intake rather than the improvement in digestibility. Therefore, we conclude that the $\mathrm{NaOH}$ 
treatment used in Israel for increasing the OM digestibility of Pima cottonseed by lactating cows might be unnecessary. However, additional performance studies with more lactating cows are needed to validate the effect of $\mathrm{NaOH}$ treatment on intake of Pima cottonseeds and on milk production. It should be noted that $\mathrm{NaOH}$ treatment makes TMR more expensive and induces less favorable storage conditions of the wet T-Pima cottonseed.

\section{CONCLUSIONS}

This study showed a slight advantage in DM, OM, $\mathrm{CP}$, lipid, and NDF digestibility in lactating cows fed TMR containing up to $18 \%$ whole linted Akala compared with whole unlinted Pima cottonseed. Treatment of Pima cottonseed with $4 \% \mathrm{NaOH}$ improved in vitro digestibility of DM and NDF. However, when the cottonseeds were included in TMR of high-producing lactating cows, digestibility of all dietary components except cellulose were similar in the 2 Pima TMR. This was reflected in similar efficiency of DMI for FCM production in cows fed the 3 types of cottonseeds. The higher DMI of cows fed the T-Pima TMR is the main cause of their greater production of milk fat, milk protein, and FCM compared with cows fed the Akala or untreated Pima TMR. This study showed that the $\mathrm{NaOH}$ treatment used in Israel for increasing the digestibility of Pima cottonseed by lactating cows might be unnecessary; however, its effect on intake and milk performance needs further validation.

\section{ACKNOWLEDGMENTS}

The authors acknowledge the assistance given by the farm staff at the Bet-Dagan dairy barn, ARO, Israel, with special thanks to S. Yakobi, Y. Portnick, L. Gurevitz, and Y. Brender.

\section{REFERENCES}

Arieli, A. 1998. Whole cottonseed in dairy cattle feeding: A review. Anim. Feed Sci. Technol. 72:97-110.
Arieli, A., Y. Aharoni, H. Tagari, S. Mabjeesh, and S. Zamwell. 1996. The effect of heating and $\mathrm{NaOH}$ treatment of non-linted whole cottonseeds on their nutritive value. J. Anim. Feed Sci. 5:215-223.

Association of Official Analytical Chemists. 2000. Official Methods of Analysis. 17th ed. AOAC Int., Gaithersburg, MD.

Clark, P. W., and L. E. Armentano. 1993. Effectiveness of neutral detergent fiber in whole cottonseed and dried distillers grains compared with alfalfa haylage. J. Dairy Sci. 76:2644-2650.

Coppock, C. E., J. R. Moya, J. W. West, D. H. Nave, J. M. Labore, and C. E. Gates. 1985. Effect of lint on whole cottonseed passage and digestibility and diet choice on intake of whole cottonseed by Holstein cows. J. Dairy Sci. 68:1198-1206.

Harvatine, D. I., J. E. Winkler, M. Devant-Guille, J. L. Firkins, N. R. St-Pierre, B. S. Oldick, and M. L. Eastridge. 2002. Whole linted cottonseed as a forage substitute: Fiber effectiveness and digestion kinetics. J. Dairy Sci. 85:1988-1999.

Kutches, A. J., W. Chalupa, and J. Trei. 1987. Delinted cottonseed improves lactation response. Feedstuffs 59:16-17.

Mabjeesh, S. J., J. Galindez, O. Kroll, and A. Arieli. 2000. The effect of roasting nonlinted whole cottonseed on milk production by dairy cows. J. Dairy Sci. 83:2557-2563.

Mertens, D. R., and J. R. Loften. 1980. The effect of starch on forage fiber digestion kinetics in vitro. J. Dairy Sci. 63:1437-1444.

Miron, J., R. Solomon, and D. Ben-Ghedalia. 1997. Digestibility by dairy cows of monosaccharide components in diets containing either ground sorghum or sorghum grain treated with sodium hydroxide. J. Dairy Sci. 80:144-151.

Moreira, V. R., L. D. Satter, and B. Harding. 2004. Comparison of conventional linted cottonseed and mechanically delinted cottonseed in diets for dairy cows. J. Dairy Sci. 87:131-138.

National Research Council. 2001. Nutrient Requirements of Dairy Cattle. 7th ed. National Academy Press, Washington, DC.

Orskov, E. R., B. J. Barnes, and B. A. Lukins. 1980. A note on the effect of different amounts of $\mathrm{NaOH}$ application on digestibility by cattle of barley, oats, wheat and maize. J. Agric. Sci. (Camb.) 94:271-273.

SAS Institute. 1996. SAS User's Guide: Statistics, version 6.12. SAS Institute Inc., Cary, NC.

Sullivan, J. L., J. T. Huber, R. L. Price, and J. M. Harper. 1993a. Comparison of digestibility, nutritive value, and storage characteristics of different forms of cottonseed in diets fed to lactating cows. J. Anim. Sci. 71:2837-2842.

Sullivan, J. L., J. T. Huber, and J. M. Harper. 1993b. Performance of dairy cows fed short Staple, Pima, and cracked Pima cottonseed and feed characteristics. J. Dairy Sci. 76:3555-3561.

Tilley, J. M., and R. M. Terry. 1963. A two-stage technique for the in vitro digestion of forage crops. J. Br. Grassl. Soc. 18:104-111.

Van Soest, P. J., J. B. Robertson, and B. A. Lewis. 1991. Methods for dietary fiber, neutral detergent fiber, and non-starch polysaccharides in relation to animal nutrition. J. Dairy Sci. 74:35833597.

Zinn, R. A. 1995. Characteristics of digestion of linted and lint-free cottonseed in diet for feedlot cattle. J. Anim. Sci. 73:1246-1250. 